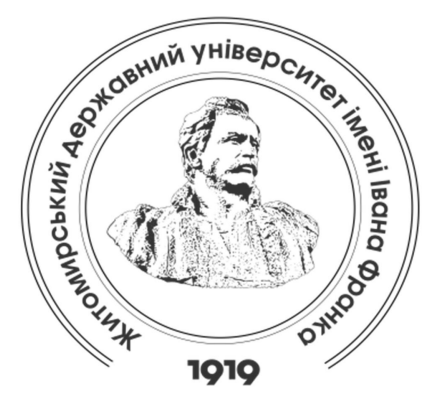

Zhytomyr Ivan Franko State University Journal. Pedagogical Sciences. Vol. 3 (102)

Вісник Житомирського державного університету імені Івана Франка. Педагогічні науки. Вип. 3 (102)

ISSN (Print): 2663-6387

ISSN (Online): 2664-0155

UDC 378.147.091.33-027.22]:159.942
DOI 10.35433/pedagogy.3(102).2020.56-62

\title{
ARTISTIC AND CREATIVE ACTIVITY AS A MEANS OF EDUCATING THE PROFESSIONAL CULTURE OF FUTURE TEACHERS OF MUSIC
}

\section{Z. M. Stukalenko*, O. M. Negrebetska ${ }^{* *}$}

The article analyzes the psychological and pedagogical aspect of the phenomenon of "culture", "artistic and creative activity". It is emphasized that the professional culture of the individual is a model of a high level of mental development and should to be the norm of social life. Different approaches of scientists to the definition of professional culture are studied. The center of scientific research was the culturological paradigm in the training of future teachers of music. The problem of culturological approach of students of music-pedagogical universities is revealed, where the categorical apparatus of personality culture is analyzed. The peculiarities of the culturological approach of the students of pedagogical universities are characterized and the place and significance of the peculiarities of the culturological approach of the students of music-pedagogical universities in the educational process are substantiated. It is proved that artistic and creative activity is an effective means of educating professional culture of students of music and pedagogical universities and is a trajectory of culturological approach. The conclusions emphasize that to educate the future musician with a unique personality, as a professional, cultural carrier and subject of interpersonal relations, it is necessary to form a system of professional and cultural values that will ensure a high level of selfawareness and self-determination of future teachers and its focus on universal values, world and national spiritual culture. Therefore, the content of the subject area covers the paradigm of the phenomena of musical art, as a format of artistic values, humanistic morality and social consciousness; concepts and principles of practical improvement of musical and pedagogical activity, which contributes to raising the level of musical culture, general cultural and aesthetic levels of students; promoting the active participation of participants in artistic events in the cultural and social life of the educational institution.

Key words: culture, professional culture, culturological approach, teacher of musical art, students, concepts, pedagogical university, artistic and creative activity.

\footnotetext{
* Candidate of Pedagogical Sciences (PhD in Pedagogy), Senior Educator (Volodymyr Vynnychenko Central Ukrainian State Pedagogical University) stukalenkoz@gmail.com ORCID: 0000-0001-5577-2655

${ }^{* *}$ Candidate of Pedagogical Sciences ( $\mathrm{PhD}$ in Pedagogy), Senior Educator (Volodymyr Vynnychenko Central Ukrainian State Pedagogical University) ua777olgas@gmail.com
} ORCID: 0000-0002-7480-6379 


\section{ХУДОЖКНО-ТВОРЧА ДІЯАЬНІСТЬ ЯК ЗАСІБ ВИХОВАННЯ ПРОФЕСІЙНОЇ КУАЬТУРИ МАЙБУТНІХ УЧИТЕАІВ МУЗИЧНОГО МИСТЕЦТВА}

\section{3. М. Стукаленко, О. М. Негребецька}

у статті проаналізовано психолого-педагогічний аспект феномену "культура", "художньо-творча діяльність". Наголошено, шо профресійна культура особистості виступае взірием високого рівня розумового розвитку людини та повинна бути нормою соиіального життя. Досліджуються різні погляди науковиів до визначення дефрініиій професійної культури. Центром наукових пошуків стала культурологічна парадигма у професійній підготовиі майбутніх учителів музичного мистеитва. Розкрито проблему культурологічного підходу студентів музично-педагогічних університетів, де проаналізовано категоріальний апарат культури особистості. Охарактеризовано особливості культурологічного спрямування студентів педагогічних університетів та обтрунтовано місие й значення в освітньому процесі особливості культурологічного підходу студентів музично-педагогічних університетів. Доведено, шо художньо-творча діяльність є ефективним засобом виховання професійної культури студентів музичнопедагогічних університетів та єе траєкторією у культурологічній ниві. у висновках акиентується увага на тому, шоб виховати майбутнього спеціаліста-музиканта з неповторною індивідуальністю, як професіонала, носія культури $i$ суб'єкта міжособистісних відносин, слід відповідно сформувати в нъого систему професійнокультурних иінностей, які забезпечуть високий рівень самосвідомості і самовизначення майбутнього виителя та його орієнтаиію на загальнолюдські иінності, світову $i$ національну духовну культуру. Тому зміст предметної області охоплюе парадигму феноменів музичного мистеитва, як формату художньо-мистеиьких иінностей, гуманістичної моралі та суспільної свідомості; поняття та приниипи практичного вдосконалення музичної та педагогічної діяльності, шо сприяе підвищенню рівня музичної культури, загальних культурного та естетичного рівнів студентів; сприяння активної участі учасників мистецьких заходів у культурно-громадському житті навчального закладу.

Ключові слова: культура, профресійна культура, культурологічний підхід, вчитель музичного мистеитва, студенти, кониерти, педагогічний університет, художньо-творча діяльність.

\begin{tabular}{|c|c|}
\hline $\begin{array}{l}\text { Introduction of the issue. } \\
\text { Professional training of future music } \\
\text { teachers is becoming one of the leading } \\
\text { priorities of the state's educational policy. } \\
\text { In this aspect the problem of professional } \\
\text { training of future teachers in the system } \\
\text { of educational work of higher educational } \\
\text { institutions is actualized, which should } \\
\text { be aimed at forming not only } \\
\text { professional, methodical, but also general } \\
\text { cultural competence, implementating } \\
\text { culturological approach in professional } \\
\text { activity. } \\
\text { Current state of the issue. Analysis } \\
\text { of research and publications is based } \\
\text { on the conceptual development of the } \\
\text { heuristic potential of pedagogy, } \\
\text { psychology, art history, culturology and } \\
\text { philosophy, developed in the research }\end{array}$ & $\begin{array}{l}\text { of scientists in the vector of } \\
\text { culturological approach, among which } \\
\text { are: A. Avdievsky, N. Alekseev. } \\
\text { L. Batkin, M. Davidov, L. Kovalchuk, } \\
\text { M. Konyk, E. Taylor, O. Shcholokova. } \\
\text { Issues of training the future music } \\
\text { teachers in the context of professional } \\
\text { and pedagogical activities are covered } \\
\text { in the works of B. Brylin, A. Rastrigina. } \\
\text { Scientists: E. Abdullin, N. Ovcharenko, } \\
\text { O. Oleksyuk, } \\
\text { O. Rudnytska, Padalka, } \\
\text { A. Sibgatullina, L. Shkolyar dealt with } \\
\text { the problem of culturological approach, } \\
\text { spiritual formation of future teachers in } \\
\text { the field of music and pedagogical } \\
\text { education. Psychological and } \\
\text { pedagogical aspects of music } \\
\text { performance are considered by }\end{array}$ \\
\hline
\end{tabular}


V. Bilous, T. Zhiginas, Yu. KhrushchevRipska, A. Martyniuk, I. Yashchenko.

Many famous scientists-musicians devoted their works to revealing the significance of the musician's performing culture: B. Asafiev, L. Barenboim, G. Gilburd, O. Gurenko, E. Lieberman, K. Martinsen, J. Milstein, G. Neuhaus, S. Savshinsky, B. Teplov, S. Feinberg.

Aim of research is to highlight the phenomenon of culturological approach in the visions of modern scientists; task - to carry out a definitive analysis of the concept of "professional culture", "culturological approach" of the source base in philosophy, culturology, art history, sociology, psychology and pedagogy; to characterize the peculiarities of the culturological approach of students of pedagogical universities with the substantiation of its place and significance in the educational process.

Results and discussion. The basis of the personal development of the future teachers of music art is the personality as a pedagogical category, which reflects the development of the teacher in the field of music education and contributes to the mastery of the experience of "being a cultural person". Professional activity accumulates all kinds of personality culture. As you know, the professional culture of the individual is the unity of professional knowledge, skills and abilities that are implemented in active creative search activities. It is, of course, related to worldviews, moral guidelines, political views, aesthetic taste, culture of thought, and so on. "Professional culture occupies a special place in the structure of personality culture, because in the process of professional activity personality culture is comprehensively and effectively implemented", - says A. Sibgatullina [5: 4]. In terms of conducting, it is appropriate to single out two important factors on which A. Avdievsky relied this is the "spiritual"culture" and "culture" [2]. A. Martyniuk remarked: "Therefore, the main task of teachers of the Faculty of Arts is to develop artistic and creative thinking of students, their cognitive activity, musical abilities and creative abilities, to form the spiritual culture of the individual in close connection with the culture of its people and its traditions, to cultivate love in future professionals. to the chosen profession [4: 268].

Instead, the culture of a music teacher researcher $\mathrm{E}$. Abdullin considers in the context of different types of music and pedagogical activities. According to the scientist, its varieties are due to "the nature of the musical art, the specifics of manifestation and development of musical abilities (musicality, musical hearing, thinking, memory, etc.), as well as types of musical activities" [1: 209].

In scientific research L. Kovalchuk and M. Konik noted that cultural orientation in its essence is a sign of a high level of professionalism of a high school teacher, and "cultural orientation is an important property of the teacher's personality and determines his worldview, creativity, values, beliefs, tastes, value-emotional attitude to himself, to students, to colleagues, to the science, the subject of which he teaches, to cultural and spiritual heritage, lifestyle, etc. It is organically connected with the pedagogical orientation and characterizes the level of professional qualities of the teacher, his professional culture, culture of professional thinking, culture of behavior and speech, etc." [3: 9]. As you know, in the process of creative and performing activities, students are given unique opportunities for self-realization, which contributes to the development of personal spiritual and moral qualities of students and increase their general level of culture, which is formed gradually in the process of socialization through education, training and personal life experience. Professional culture, from the point of view of 
O. Shcholokova, is a system of formation and rethinking of value orientations, the condition of which is the activity approach, which "provides for the creation of pedagogical conditions and situations in which equality of communication and emotional openness is ensured not only between students but also between teachers. and students" [9: 42]. The modern system of higher art education is rich in various forms of formation of the creative personality of future music teachers. The training of highly qualified music teachers, who have a comprehensive music-performing and music-theoretical training, is carried out in the process of studying at the music-pedagogical and art faculties of pedagogical institutions of higher education. The implementation of tasks is carried out through the introduction into the system of teaching the following types of musical and performing activities of students: a) the study of different styles and genres of instrumental, vocal, vocalinstrumental, choral and orchestral works; b) reading from a sheet; c) accompaniment to own singing; d) transposition of a simple composition; e) selection of melody and accompaniment by ear.

As a result of studying academic disciplines, the student must have a systematic, complete, solid knowledge in the scope and within the requirements of the curriculum, consciously use them in solving current problems of music education, in the analysis of teaching materials, curricula and curricula. programs, draw the right conclusions, make informed decisions and develop a professional culture in the choice of repertoire.The foundation of the development of general musical culture of students is a cycle of musictheoretical disciplines, which "combines the study of the history of foreign, domestic and modern music, music theory, solfeggio, harmony, analysis of musical forms, theory and methods of music education. user arrangement and sound recording, choir class, solo singing, orchestra class, main musical instrument, additional musical instrument, choral conducting, orchestral conducting" [6: 4]. Thus, the nature of individual classes contributes to the flexible, differentiated and systematic formation of all components of creative and cultural development of students. The purpose and task of the discipline "Basic musical instrument" is to prepare students for the free use of the instrument during the lesson and extracurricular musical and educational work in secondary school. The main tasks of studying the discipline: artistic and executive development of students; formation of musical and pedagogical skills of future teachers; education of their creative abilities; accumulation of performing "baggage" for all types of musical and educational work; mastering the method of teaching the main musical instrument in secondary schools; involvement of students in cultural heritage; designing one's own professional activity; formation of stage culture, mastering of stage freedom, development of artistry; formation of musical taste in future music teachers.

"Basic musical instrument" is a kind of branch of theoretical musicology, which requires from the future teacher not only deep knowledge, but also a bright personality, manifestations of creative intuition and psychological sense. This is necessary both for understanding the content of a musical work, and for creative contacts with students, which can be carried out only under the condition of personal empathy, joint artistic experience. The significance of these moments is especially great because they coincide with the fundamental features of musical talent, which is known to have a communicative nature, the core of which is art education, which involves the formation of creative, active 
musician capable of embracing a wide range of cultural values.

The breadth, variety of techniques, forms and methods of individual work contribute to the effective implementation of the abilities and creative forces of the student's personality, his cultural development. However, the most effective form of developing a student's creative abilities is an orchestral ensemble. It is in the orchestra class that abilities are formed and creative opportunities are developed that influence the professional development of future music teachers. In Ukraine, orchestral work occupies an important place in the professional activity of a music teacher. In preparing students to work with orchestras and ensembles, it is recommended to use active teaching methods, one of which is the modeling of pedagogical situations.

To this end, a workshop with an orchestra (ensemble) has been introduced into the structure of the training orchestra (ensemble), which is mandatory for senior students. The participation of primary school students in this workshop is limited to the following tasks: modeling the activities of student orchestra members; creation of non-standard pedagogical situations; performance of educational tasks set by the trainee conductor; observation of the work of undergraduates with the orchestra, analysis and evaluation of their own activities; orchestra conducting (rehearsal technique); sketch work on works that can be used in work with student orchestras or instrumental ensembles. The selection of the repertoire in the orchestra class is based on the following criteria: ideological and artistic value of the works; variety of genres and themes; multifaceted use of works (from tests to concert performance); availability in technical and artistic terms; the sequence of growth of the executive level of the team; interest of the leader and orchestrators.

In Choral Class programs, it is important to create a system of work so that in the future the choir leader can focus his creative thought on the development of emotionality, artistic taste, singing skills and the ability to lead the choir. Therefore, personalized requirements in the "Choral Classroom" require the formation of students' skills of conscious and professional artistic performance of works, the development of auditory, vocal and choral skills and the ability to establish a positive microclimate in the team. Researcher V. Cherkasov believes: "The leading role in creating a tolerant environment belongs to the artistic director, conductor or author of the creative project" [8: 121]. Therefore, of great importance in working with the choir are the properties of the leader - the ability to control themselves, listen to the interlocutor, be friendly. Thus, the professional culture of the future music teacher should include respect for the identity and individuality of each member of the team.

From these positions, the priority areas of pedagogical activity in higher education institutions are the formation of future teachers of music art professional competencies in the field of cultural process, namely: active sociocultural creativity; strengthening the cultural orientation of extracurricular activities; openness to the multicultural, polyethnic environment with a developed national consciousness. Under such conditions, the emphasis in teaching the course "Choral Class" should be organized on the creative self-realization of students, active involvement in the creation of students' own cultural space of life. A modern school needs a new generation of teachers who have a high professional culture, professional competence and are able to objectively comprehend pedagogical phenomena and facts. According to O. Rostovsky 
"this is a reality that should be taken into account in the process of professional training of future music teachers" [6: 15].

Thus, in the process of formation of professional and pedagogical culture of students by means of orchestral and choral activity the basis is the development of emotional culture; expansion of artistic and aesthetic experience; the development of empathy as conditions for the reproduction of the sensory experience of mankind and the transformation of universal values in the individual consciousness of the individual; education of creative personality by means of development, awareness, realization of one's own worldview in choral singing, creative tasks, interpretation of artistic image as creative self-realization; acquisition by students of culture of coexistence in collective.

Along with the choir class, vocal training occupies a prominent place in the professional development of future teachers. According to the analysis of the programs, students must master the performing skills of solo singing, be able to analyze the artistic idea of the work and express their own attitude to music. In the curricula of "Vocal class" and "Voice production" it is noted that during the period of study in the free educational and pedagogical profile students must use methods based on sound knowledge and personal experience. The programs focus on the importance of an individual approach. Professional training of a future music teacher is impossible without the formation of his vocal culture. Students must be free to operate with singing skills that are basic in the process of forming vocal culture, to navigate in the styles and genres of vocal art and know the features of stage culture. The high level of vocal culture is characterized by compliance with the basic requirements of vocal performance and should be based on their mastery of deep knowledge in the field of vocal music, such as: free and beautiful sound, articulation, art and artistry, stage culture.

Graduates of art and musicpedagogical faculties must master performing skills, as indicated in the programs of the music-instrumental cycle. The future music teacher must learn to transpose, translate and adapt musical works according to their own performance capabilities, taking into account artistic approaches to the creative process. Therefore, the instrumental training of the future teacher should not be limited to a purely "craft" acquisition of competencies, but to broadcast the work in the field of culturological approach. Graduates must demonstrate the ability to meaningful, meaningful performance, understanding of the author's intention and mastery of a wide range of means of musical expression.

Artistic and pedagogical interpretation of music as a type of educational activity contributes to new searches for artistic and integration ways. "Students should realize that in the system of music-pedagogical education, which has its own specifics, musical-performance interpretation of works is aimed at work in further professional activities, ie is aimed at children," - said N. Ovcharenko [5: 75]. Therefore, future teachers must be able to optimize their further work, where the appropriate place should have: accessibility and brightness of interpretation of the work, the ability to emphasize the main thing in the musical image, that is, unobtrusively interpret the work; be able to interest children in their own example.

Thus, the peculiarities of the culturological approach of the future music teacher are, first, the process and content of professional training, which significantly affects the level of professional training of students and leads to self-realization, selfdetermination and self-affirmation. 
Secondly, the influence of music on the development of personal qualities and creative abilities. Music promotes the development of emotional, social values of man, making him more liberal and able to perceive "others" as "their own". This aspect is manifested as a special ability to reproduce, interpret, empathize with works of musical art, to form a professional culture.

Conclusions and research perspectives. Thus, artistic and creative activity as a means of educating the professional culture of students of pedagogical universities includes such definitions as: stage culture of students; realization of tasks of pedagogical artcommunicative activity of the future teacher of music in the course of educational employment and practical activity through introduction of integrative models of activity; selfactualization of students in the formation of the core elements of pedagogical and performing skills, which is provided by the formation of musical competencies; formation of a creative, comprehensively cultural personality of a music teacher. Prospects for further research are indepth analysis of scientific developments of theoretical concepts of cultural training of future teachers of music.

\section{REFERENCES (TRANSLATED \& TRANSLITERATED)}

1. Abdullin, E.B. (2004). Teoriya muzykalnogo obrazovaniya: uchebnik. [The theory of musical education: textbook] [in Russian].

2. Avdiyevsky, A.T. (1992). Na khvylyakh vidrodzhennya. Muzyka [On the waves of revival. Music] [in Ukrainian].

3. Kovalchuk L., \& Konyk M. (2009). Kulturolohichna spryamovanist yak oznaka vysokoho rivnya profesionalizmu vykladacha vyshchoyi shkoly. [Culturological orientation as a sign of a high level of professionalism of a higher school teacher] [in Ukrainian].

4. Martynyuk, A.K.

(2020). Stanovlennya khudozhnoho svitohlyadu ta pedahohichnykh pohlyadivformation IOf artistic worldview and pedagogical views] [in Ukrainian].

5. Ovcharenko, N.A.

(2013). Kulturolohichnyy pidkhid u profesiyniy pidhotovtsi maybutnoho vchytelya muzychnoho mystetstva [Culturological approach in the training of future teachers of music] [in Ukrainian].

6. Rostovskyy, O.Ya.

(2011). Teoriya $i$ metodyka muzychnoyi osvity [Theory and methods of music education] [in Ukrainian].

7. Sibgatullina, A.A. Formirovaniye kulturologicheskoy kompetentsii budushchego uchitelya inostrannogo yazyka natsionalnoy shkoly [Formation of cultural competence of the future teacher of a foreign language of the national school] [in Russian].

8. Cherkasov, V.F. (2013). Teoriya $i$ metodyka muzychnoyi osvity: navch. posib. [Theory and methods of music education: textbook] [in Ukrainian].

9. Shcholokova, O.P. (1996). Osnovy profesiynoyi khudozhnoestetychnoyi pidhotovky maybutnoho vchytely [Fundamentals of professional artistic and aesthetic training of future teachers] [in Ukrainian].

Received: August 06, 2020 Accepted: September 14, 2020 